\title{
Growth, secondary metabolism, and related gene expression in response to interactions of nitrogen and sulfur in Isatis indigotica
}

\author{
Y.J. MIAO ${ }^{1}$, R.J. QU ${ }^{1}$, J.T. SHA ${ }^{1}$, Y.W. CAO ${ }^{1}$, J.L. GUAN ${ }^{1}$, J. XU ${ }^{1}$, X.Q. TANG ${ }^{1 *}$, F.Q WANG ${ }^{2}$, \\ and J. YANG ${ }^{2}$ \\ College of Horticulture, Nanjing Agricultural University, Nanjing, 210095, P.R. China ${ }^{1}$ \\ Institute of Food Crops, Jiangsu Academy of Agricultural Sciences, Nanjing 210014, P.R. China ${ }^{2}$
}

\begin{abstract}
Nitrogen and sulfur are major elements influencing plant growth and production of secondary metabolites. They interact to each other, but little is known about it in Isatis indigotica Fort. plants. In this study, 15 different treatments representing all possible combinations of $3 \mathrm{~N}$ treatments (N1, N2, and N3, corresponding to 5, 15, and $25 \mathrm{mM} \mathrm{N}$, respectively) and five S treatments (S0, S1, S2, S3, and S4, corresponding to $0.00,1.25,2.50,5.00$ and $7.50 \mathrm{mM} \mathrm{S}$, respectively) were used, and plant growth, indigo and indirubin yields, and expressions of genes encoding enzymes involved in $\mathrm{N}$ and $\mathrm{S}$ metabolisms were measured. The results show that the highest dry biomass was observed in N2S2 treatment. Moreover, net photosynthetic rate in the N2S2 treatment was significantly higher than under other treatments (except for N3S2 treatment). A low nitrogen concentration $(5 \mathrm{mM})$ was beneficial to the accumulation of alkaloids, and the N1S1 and N2S2 treatments resulted in the highest yields of indigo and indirubin, respectively. Additionally, the yields of indigo and indirubin were positively correlated with the expression of APS reductase and glutamine synthetase genes, respectively.
\end{abstract}

Additional key words: indigo, indirubin, photosynthetic rate, RT-qPCR, stomatal conductance, transpiration rate.

\section{Introduction}

Mineral nutrition affects metabolic processes in plants and thus also the useful products of secondary metabolism (Herms et al. 1992). Nitrogen and sulfur are two essential macronutrients and function in numerous processes (Kopriva et al. 2015). It has been suggested that the accumulation of alkaloids in plant tissues is closely correlated with $\mathrm{N}$ concentration in the soil. For example, the vinblastine and vincristine content of Catharanthus roseus are highest at a moderate nitrogen concentration (Singh et al. 2015). In Sencio jacobaea, the content of total viroxane alkaloids decrease significantly as $\mathrm{N}$ concentration increases (Hol et al. 2003). Previous studies demonstrated that a low concentration of inorganic $\mathrm{N}$ in the soil reduces S uptake and assimilation (Davidian et al. 2010). Also, it has been reported that $S$ deprivation results in a disruption of $\mathrm{N}$ metabolism by a reduction of nitrate reductase activity (De Bona et al. 2011, Sorin et al. 2015) or by a limitation of protein synthesis (Hesse et al. 2004). Thus, optimal nutrition can affect primary metabolism and subsequently regulates secondary metabolism including alkaloids.

Medicinal plants play an important role in the prevention and treatment of human diseases. Thus, the cultivation of medicinal plants does not focus only on yields but also on the content of secondary metabolites. Isatis indigotica Fort. is a biennial herbaceous plant of the Cruciferae family, which is widely distributed and cultivated in China. Its dry leaves are used in a traditional Chinese medicine. The pharmacological activity of I. indigotica is due to its alkaloids, organic acids, glycosides, sterols, etc (Zhou and Zhang 2013). The most important components are indirubin and indigo. Besides the work on their isolation and therapeutic potential, research is needed to enhance the production of

Submitted 24 July 2018, last revision 11 December 2018, accepted 13 December 2018.

Abbreviations: APR - APS reductase; APS - adenosine phosphosulfate; ATPS - ATP sulfurylase; $c_{i}$ - intercellular $\mathrm{CO}_{2}$ concentration;

E - transpiration rate; GDH - glutamate dehydrogenase; GOGAT - glutamate synthase; $g_{s}$ - stomatal conductance; GS - glutamine synthetase; NR - nitrate reductase; OAS-TL - cysteine synthase; $\mathrm{P}_{\mathrm{N}}$ - net photosynthetic rate.

Acknowledgments: This work was supported by the National Natural Science Foundation of China (Grant no. 31171486).

* Corresponding author; fax: (+86) 02584395150, e-mail: xqtang@njau.edu.cn 
of medicinally important metabolites. In our previous report, we have established the role of $\mathrm{N}$ forms and their content in biomass yield, and indigo and indirubin accumulations (Xiao et al. 2013). Previous studies have paid little attention to the interactions of $\mathrm{N}$ and $\mathrm{S}$ on the growth and metabolism of I. indigotica. Furthermore, they have not clarified how the expressions of genes involved in the metabolism of $\mathrm{N}$ and $\mathrm{S}$ respond to different applications of $\mathrm{N}$ and $\mathrm{S}$. The present study aims to assess the effects of different ratios of $\mathrm{N}$ and $\mathrm{S}$ on growth, indigo and indirubin yields, and gene expressions of enzymes involved in the metabolism of $\mathrm{N}$ and $\mathrm{S}$ in I. indigotica seedlings. Data generated by this study were expected to be of a great value for understanding the effects of $\mathrm{N}$ and $\mathrm{S}$ on indigo and indirubin yields in I. indigotica.

paper was soaked chloroform for $15 \mathrm{~h}$, and then put into tube extractors with chloroform and heated until the extraction solution became colourless. After the chloroform volatilized, the samples were dissolved in methanol and transferred to $10-\mathrm{cm}^{3}$ flasks, diluted with $10 \mathrm{~cm}^{3}$ of methanol, and mixed. The samples were then filtered using $0.45 \mu \mathrm{m}$ microfiltration membranes.

Ultra performance liquid chromatography was conducted using a method specifically developed for Chinese pharmacopeia (Chinese Pharmacopoeia Commission 2015), and an Agilent ZORBAX-Eclipse-Plus $\mathrm{C}_{18}$ column $(2.1 \mathrm{~mm} \times 50 \mathrm{~mm}, 1.8 \mu \mathrm{m}$ film thickness $)$ was used. Column temperature was $30^{\circ} \mathrm{C}$. The mobile phase was consisted of methanol and water $(72: 28, \mathrm{v} / \mathrm{v})$ and set at a flow rate of $0.3 \mathrm{~cm}^{3} \cdot \mathrm{min}^{-1}$. Samples of $2 \mathrm{~mm}^{3}$ were automatically injected and analyzed using UV radiation at $289 \mathrm{~nm}$. Each compound was quantified using a specific external standard.

Gene selection, primer design, and RT-qPCR: Seven target genes and one reference gene from the I. indigotica transcriptome data were identified. Primers were designed based on their sequences using the Primer Premier 5.0 software with following criteria: a GC content of $45-65 \%$, an optimal melting temperature of $58-61{ }^{\circ} \mathrm{C}$, a primer length of $19-26 \mathrm{bp}$, and an amplicon length of 80 - 200 bp (Table 2 Suppl.). Primer specificity was judged by melting-curve analysis and $2 \%(\mathrm{~m} / \mathrm{v})$ agarose gel electrophoresis of the amplification products (Fig. 1 Suppl.).

Total RNA from various tissue samples was isolated using an RNA simple total RNA kit (Tiangen, Nanjing, China). The RNA concentration of each sample was determined using a NanoDrop-2000 spectrophotometer (Thermo Fisher Scientific, Wilmington, USA). Samples with a 260/280 nm ratio between 1.9 and 2.1 , and a $260 / 230 \mathrm{~nm}$ ratio $\geq 2.0$ were chosen to determine the quality and purity of the RNA preparations. The integrity of the purified RNA was checked by $1.0 \%$ agarose gel electrophoresis. Subsequently, the first-strand cDNA was synthesized from RNA (300 ng mm $\mathrm{mm}^{-3}$ ) in $20 \mathrm{~mm}^{3}$ of a reaction mixture using a PremeScript ${ }^{\mathrm{TM}} \mathrm{RT}$ reagent kit with a gDNA eraser (TaKaRa, Dalian, China) following the manufacturer's protocol.

Three biological replicates from each treatment were subjected to the reverse transcription quantitative PCR 
assay using the SYBR Green methodology and an ABI 7500 real-time PCR system (Applied Biosystems, Foster City, USA) with Actin as a reference gene. A PCR reaction was prepared in a $20 \mathrm{~mm}^{3}$ volume containing: $2 \mathrm{~mm}^{3}$ of a 5-fold diluted synthesized cDNA, $10 \mathrm{~mm}^{3}$ of a real-time PCR Master Mix, $2 \mathrm{~mm}^{3}$ of each primer, $0.4 \mathrm{~mm}^{3}$ of ROX1 $(50 \times)$, and $5.6 \mathrm{~mm}^{3}$ of double distilled $\mathrm{H}_{2} \mathrm{O}$. A reaction comprised an initial step at $95{ }^{\circ} \mathrm{C}$ for $10 \mathrm{~min}$ followed by 40 denaturation cycles at $95{ }^{\circ} \mathrm{C}$ for $5 \mathrm{~s}$ and primer annealing at $60{ }^{\circ} \mathrm{C}$ for $30 \mathrm{~s}$. Next, melting curves ranging from 60 to $95{ }^{\circ} \mathrm{C}$ were evaluated in each reaction to check the specificity of the amplification products. Relative fold expression changes were calculated using the $2^{-\Delta \Delta C T}$ method (Livak and Schmittgen 2001).

Statistical analysis: Data were statistically analyzed using the SPSS software (v. 19.0;IBM, USA), and tested for homogeneity of variance by means of least significant difference multiple range tests at the level of 0.05. Graphs were drawn with the Origin (v. 9.0; Origin Lab, Massachusetts, USA).

\section{Results}

Plants were irrigated with a nutrient solution with different $\mathrm{N}$ and $\mathrm{S}$ ratios. For the N2S2 treatment, total dry mass per plant was significantly higher than in other treatments, about 2-times higher (Fig. 1). It shows that a proper $\mathrm{N}$ and $\mathrm{S}$ application can indeed optimize plant growth. The effect of $\mathrm{N}$ or $\mathrm{S}$ applications on the total dry mass suggests that moderate concentrations were most appropriate, and the $\mathrm{N} 2$ and S2 treatments generated the highest plant growth.

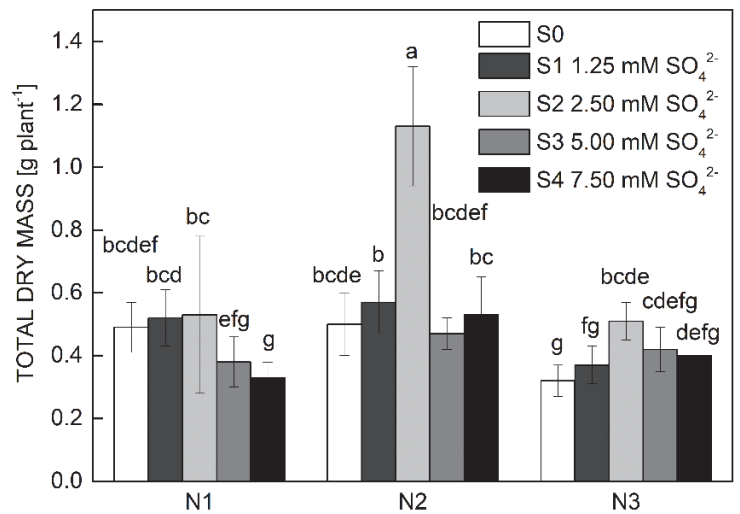

Fig. 1. Total dry mass of Isatis indigotica leaves exposed to different concentrations of nitrogen (N1, N2, and N3: 5, 15, and $25 \mathrm{mM} \mathrm{NH}_{4} \mathrm{NO}_{3}$, respectively) and different concentrations of sulfur (S0: 0.00; S1: $1.25 \mathrm{mM} \mathrm{MgSO}_{4} ; \mathrm{S} 2: 2.50 \mathrm{mM} \mathrm{MgSO}_{4} ; \mathrm{S} 3$ : $2.50 \mathrm{mM} \mathrm{MgSO}_{4}$ and $2.50 \mathrm{mM} \mathrm{K}_{2} \mathrm{SO}_{4}$; $\mathrm{S} 4: 2.50 \mathrm{mM} \mathrm{MgSO}_{4}$, $2.50 \mathrm{mM} \mathrm{K}_{2} \mathrm{SO}_{4}$, and $\left.2.50 \mathrm{mM} \mathrm{CaSO}_{4}\right)$. Means $\pm \mathrm{SDs}, n=10$, values followed by different letters are significantly different $(P$ $\leq 0.05)$.

Net photosynthetic rate depended on S concentration, $\mathrm{P}_{\mathrm{N}}$ firstly increased and then decreased when the $\mathrm{S}$ concentration increased (Table 1). However, the effect of $\mathrm{N}$ concentration on $\mathrm{P}_{\mathrm{N}}$ was not significant. Overall, $\mathrm{P}_{\mathrm{N}}$ in the N2S2 and N3S2 treatments was higher than under other treatments, which indicates that suitable $\mathrm{N}$ and $\mathrm{S}$ ratios could effectively improve $\mathrm{P}_{\mathrm{N}}$ promoting dry mass accumulation in I. indigotica seedlings. On the contrary, intercellular $\mathrm{CO} 2$ concentration was obviously lower under the N3S2 treatment than in other treatments (except for the N3S0). There were no significant differences among most treatments. Stomatal conductance and transpiration rate firstly increased and then decreased as the $\mathrm{S}$ concentration increased (Table 1).

The highest yields of indigo and indirubin were $7.38 \mu \mathrm{g} \cdot \mathrm{g}^{-1}$ (plant d.m.) and $2.58 \mu \mathrm{g} \mathrm{g}^{-1}$ (plant d.m.) in the N1S1 and N2S2 treatments, respectively. However, under a higher $\mathrm{N}$ concentration, a significant decrease in the yields of indigo and indirubin were observed. Also, a high concentration of $\mathrm{S}$ caused a reduction in the yields of indigo and indirubin, and the moderate $\mathrm{S}$ application increased them (Table 2).

When analyzing the transcription of the different genes related to $\mathrm{N}$ metabolism enzymes, we observed that the $\mathrm{N} 3$ significantly increased expression of the nitrate reductase $(N R)$ gene: its relative expression increased by about 3.2-, 11.0-, 9.3-, 11.3-, and 15.2-fold under S0, S1, S2, S3, and $\mathrm{S} 4$ treatment groups, respectively, in comparison to $\mathrm{N} 1$ (Fig. 2A). The glutamine synthetase (GS) and glutamate synthase (GOGAT) genes were strongly down-regulated under the N3 concentration (Fig. 2B,D). Meanwhile, the positive effect of the moderate $\mathrm{N}$ concentration (N2) on glutamate dehydrogenase $(G D H)$ gene expression was found (Fig. 2C). Comparing gene expressions with increasing $\mathrm{S}$ concentration, it was found that $N R, G S$, $G D H$, and GOGAT genes mostly first increased and then decreased. For example, at N2, the largest expression of the $G S$ gene was observed in combination with $\mathrm{S} 2$, which was 4.7-, 1.5-, 4.1-, and 92.0-fold higher in comparison to $\mathrm{S} 0, \mathrm{~S} 1, \mathrm{~S} 3$, and $\mathrm{S} 4$, respectively (Fig. $2 B$ ). Finally, no significant difference was observed in expression of $G S$ and GOGAT genes under the N3 treatment (Fig. 2BD).

The expression of genes related to $\mathrm{S}$ metabolism enzymes did not follow a fixed pattern under different treatments. The relative expression of the adenosine phosphosulfate reductase $(A P R)$ gene was significantly up-regulated under N1, which was 7.7-, 18.2-, 8.2-, 6.1and 6.8-fold, respectively, higher than under N3 (Fig. 3B). But, no clear change of ATP sulfurylase (ATPS) and cysteine synthase $(O A S-T L)$ gene expressions were found under different $\mathrm{N}$ applications. The ATPS and APR gene relative expressions were significantly up-regulated under 


\section{Y.J. MIAO et al.}

Table 1. Effect of different nitrogen and sulfur treatments on net photosynthetic rate $\left(\mathrm{P}_{\mathrm{N}}\right)$, stomatal conductance $\left(\mathrm{g}_{\mathrm{s}}\right)$, intecellular $\mathrm{CO}_{2}$ concentration $\left(\mathrm{c}_{\mathrm{i}}\right)$, and transpiration rate $(\mathrm{E})$ of Isatis indigotica. Means \pm SDs, $n=5$. Different letters indicate significant differences between treatments using the Dunnett test at $P \leq 0.05$. For different treatments, see Fig. 1 .

\begin{tabular}{lllll}
\hline Treatments & $\mathrm{P}_{\mathrm{N}}\left[\mu \mathrm{mol} \cdot \mathrm{m}^{-2} \cdot \mathrm{s}^{-1}\right]$ & $\mathrm{gs}_{\mathrm{s}}\left[\mathrm{mol} \cdot \mathrm{m}^{-2} \cdot \mathrm{s}^{-1}\right]$ & $\mathrm{c}_{\mathrm{i}}\left[\mu \mathrm{mol} \cdot \mathrm{mol}^{-1}\right]$ & $\mathrm{E}\left[\mathrm{mmol} \cdot \mathrm{m}^{-2} \cdot \mathrm{s}^{-1}\right]$ \\
\hline $\mathrm{N} 1 \mathrm{~S} 0$ & $11.22 \pm 0.77 \mathrm{fg}$ & $0.30 \pm 0.05 \mathrm{bc}$ & $313.71 \pm 7.86 \mathrm{a}$ & $5.33 \pm 0.55 \mathrm{abc}$ \\
$\mathrm{N} 1 \mathrm{~S} 1$ & $13.37 \pm 0.29 \mathrm{abc}$ & $0.35 \pm 0.04 \mathrm{bc}$ & $310.25 \pm 6.78 \mathrm{a}$ & $5.59 \pm 0.34 \mathrm{abc}$ \\
$\mathrm{N} 1 \mathrm{~S} 2$ & $14.00 \pm 0.89 \mathrm{ab}$ & $0.43 \pm 0.10 \mathrm{ab}$ & $314.69 \pm 9.68 \mathrm{a}$ & $6.70 \pm 0.83 \mathrm{ab}$ \\
$\mathrm{N} 1 \mathrm{~S} 3$ & $13.23 \pm 0.93 \mathrm{abcd}$ & $0.42 \pm 0.05 \mathrm{ab}$ & $317.88 \pm 1.26 \mathrm{a}$ & $6.74 \pm 0.37 \mathrm{ab}$ \\
N1S4 & $10.72 \pm 0.69 \mathrm{~g}$ & $0.28 \pm 0.11 \mathrm{bc}$ & $302.93 \pm 23.32 \mathrm{ab}$ & $5.27 \pm 1.20 \mathrm{abc}$ \\
N2S0 & $11.75 \pm 0.01 \mathrm{defg}$ & $0.54 \pm 0.00 \mathrm{a}$ & $324.99 \pm 0.06 \mathrm{a}$ & $6.28 \pm 0.00 \mathrm{ab}$ \\
N2S1 & $11.95 \pm 0.00 \mathrm{cdefg}$ & $0.19 \pm 0.00 \mathrm{c}$ & $263.30 \pm 0.06 \mathrm{~cd}$ & $4.00 \pm 0.00 \mathrm{c}$ \\
N2S2 & $14.29 \pm 0.41 \mathrm{a}$ & $0.44 \pm 0.15 \mathrm{ab}$ & $307.44 \pm 21.06 \mathrm{a}$ & $6.88 \pm 1.27 \mathrm{a}$ \\
N2S3 & $11.64 \pm 2.00 \mathrm{efg}$ & $0.34 \pm 0.24 \mathrm{bc}$ & $295.61 \pm 39.49 \mathrm{ab}$ & $5.48 \pm 2.44 \mathrm{abc}$ \\
N2S4 & $11.45 \pm 1.28 \mathrm{efg}$ & $0.39 \pm 0.17 \mathrm{ab}$ & $316.36 \pm 13.02 \mathrm{a}$ & $6.31 \pm 1.59 \mathrm{ab}$ \\
N3S0 & $12.62 \pm 0.31 \mathrm{bcdef}$ & $0.18 \pm 0.04 \mathrm{c}$ & $244.12 \pm 21.76 \mathrm{~d}$ & $4.06 \pm 0.74 \mathrm{c}$ \\
N3S1 & $12.89 \pm 0.45 \mathrm{abcde}$ & $0.55 \pm 0.10 \mathrm{a}$ & $321.45 \pm 6.85 \mathrm{a}$ & $6.43 \pm 0.49 \mathrm{ab}$ \\
N3S2 & $14.31 \pm 1.16 \mathrm{a}$ & $0.29 \pm 0.03 \mathrm{bc}$ & $277.40 \pm 10.81 \mathrm{bc}$ & $5.86 \pm 0.60 \mathrm{ab}$ \\
N3S3 & $11.65 \pm 0.40 \mathrm{efg}$ & $0.35 \pm 0.06 \mathrm{bc}$ & $306.51 \pm 11.40 \mathrm{a}$ & $4.99 \pm 0.39 \mathrm{bc}$ \\
N3S4 & $10.86 \pm 0.58 \mathrm{~g}$ & $0.34 \pm 0.04 \mathrm{bc}$ & $309.12 \pm 7.63 \mathrm{a}$ & $5.00 \pm 0.40 \mathrm{bc}$ \\
\hline
\end{tabular}

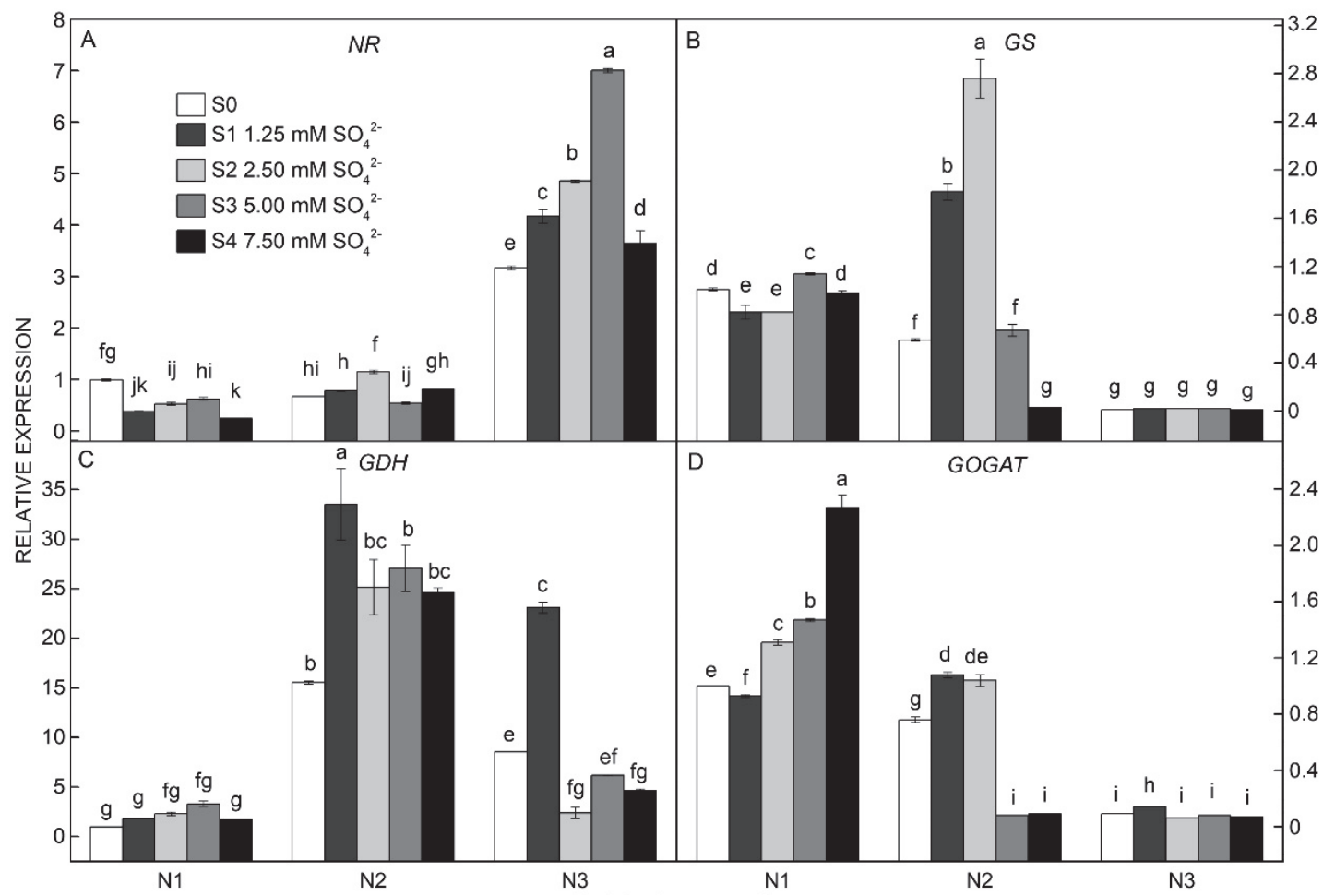

Fig. 2. Relative expressions of genes encoding nitrogen metabolism enzymes of Isatis indigotica under different concentrations of nitrogen and sulfur. Means $\pm \mathrm{SDs}, n=3$, different letters indicate significant differences $(P \leq 0.05)$. For different treatments, see Fig. 1 . $N R$ - nitrate reductase, GS - glutamine synthetase, GDH - glutamate dehydrogenase, GOGAT - glutamate synthase.

\section{S deficiency (Fig. 3ABC).}

Correlation analysis shows that the expression of the GOGAT gene was positively correlated with the expressions of the GS gene, and $A P R$ gene (Table 3), whereas the expression of the $N R$ gene was negatively correlated with the expressions of the GS, GOGAT, and
$A P R$ genes. Additionally, the expression of the $G D H$ gene was negatively correlated with the expression of the $A P R$ gene. Interestingly, the indigo and indirubin yields were positively correlated with the expressions of $A P R$ and $G S$ genes, respectively. Moreover, under different $\mathrm{N}$ and $\mathrm{S}$ concentrations, the indigo and indirubin yields showed a 
significant mutual correlation. It was suggested that the accumulation of products of secondary metabolism might be correlated with the primary metabolic enzyme expressions in I. indigotica.

Principle component analysis aimed to establish relationships between different ratios of $\mathrm{N}$ and $\mathrm{S}$ based on the biochemical parameters and the expressions of genes related to the metabolism of $\mathrm{N}$ and $\mathrm{S}$ (Fig. 4.). The analysis showed that 1) there were differences between treatments as indicated by the degrees of separation, 2) there were clear interactions between $\mathrm{N}$ and $\mathrm{S}$ as indicated by separation between treatments at a given level of $\mathrm{N}$ or $\mathrm{S}$, and 3) the N2S2 treatment clearly stood out from other treatments.

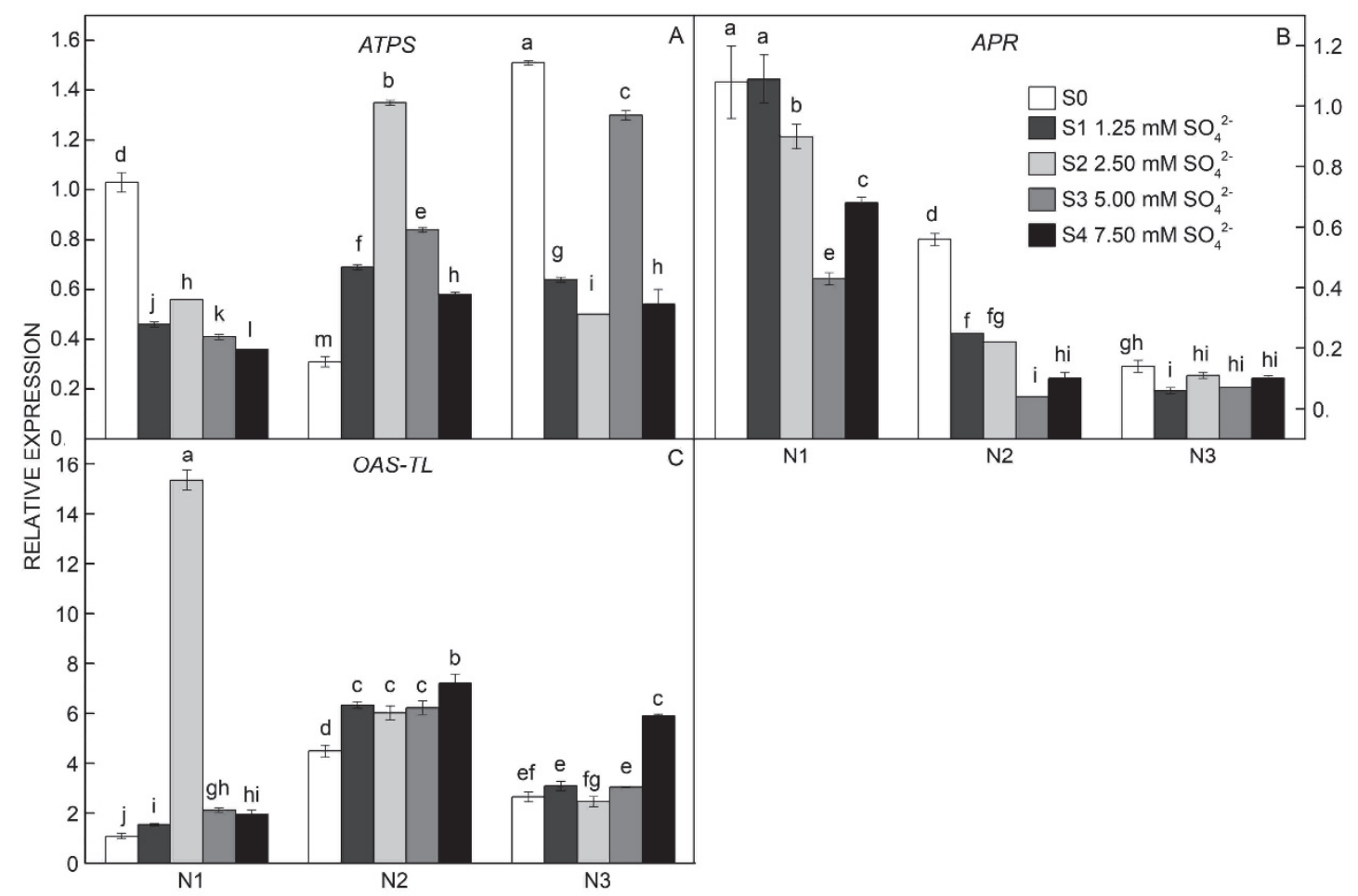

Fig. 3. Relative expressions of genes encoding sulfur metabolism enzymes in Isatis indigotica under different concentrations of nitrogen and sulfur. Means \pm SDs, $n=3$, different letters indicate significant differences $(P \leq 0.05)$. For different treatments, see Fig. 1. ATPS - ATP sulfurylase, APR - adenosine phosphosulfate reductase, $O A S-T L$ - cysteine synthase.

\section{Discussion}

In this investigation, the accumulation of dry matter in I. indigotica was promoted under $15 \mathrm{mM} \mathrm{N}$ and $2.5 \mathrm{mM} \mathrm{S}$, and no significant difference was found among other treatments (Fig. 1). The positive effects of suitable $\mathrm{N}$ and $\mathrm{S}$ ratios on growth and biomass accumulation was coincident with previous reports in other medicinal and crop plants (Salvagiotti et al. 2009, Tsujimoto et al. 2017, Raza et al. 2018). The reason might be an enhanced nitrogen use efficiency (Salvagiotti and Miralles 2008). In addition, the increase of biomass production required an increase in photosynthetic carbon fixation as in average 40 $\%$ saccharides form dry mass of wheat (Murchie et al. 2009, Parry et al. 2011). Here, we observed that $P_{N}$ in the N2S2 treatment was significantly higher than in other treatments (except for the N3S2 treatment) (Table 1), which was correlated with the total dry mass. Thus, we assume that the accumulation of the total dry mass in $I$. indigotica could be enhanced by improving the efficiency of photosynthetic carbon fixation under an optimal N/S ratio.

Alkaloids are important N-containing secondary metabolites. At present, there are about 1600 known alkaloids (Wink 2003) and indigo and indirubin belong to the indole alkaloid family. Therefore, the biosyntheses of indigo and indirubin are directly or indirectly related to the $\mathrm{N}$ and $\mathrm{S}$ content. The highest yields of indigo and indirubin were found under a moderate $\mathrm{N}$ concentration (Table 2). The higher $\mathrm{N}$ concentrations facilitated plant growth and $\mathrm{N}$ metabolism, but failed to increase the accumulation of secondary metabolites. Guan et al. (2018) also reported that low nitrogen applications promote indigo and indirubin content. Moreover, the accumulation of secondary metabolites is also influenced by transportation and distribution among cells or tissues, and also by their degradation (Zhao et al. 1999). These are complex processes that need to be further studied. Optimal $\mathrm{N}$ and $\mathrm{S}$ 
ratios are therefore important for the cultivation of medicinal plants.

Nitrogen is a vital component of living matter (Rentsch et al. 2007) and $\mathrm{S}$ is considered as the fourth main plant nutrient after nitrogen, phosphorus, and potassium (Scherer 2001). It is well known that $\mathrm{N}$ and $\mathrm{S}$ are essential in primary and secondary metabolism (Aharoni and Galili 2011, Maeda and Dudarev 2012, Giordano and Raven 2014). As expected, the results obtained by correlation analysis show that the yields of indigo and indirubin were correlated with the expressions of $A P R$ and $G S$ genes (Table 3). As a key enzyme in the $\mathrm{S}$ metabolism pathway, APR plays an important role in synthesis of amino acids or proteins (Leustek and Saito 1999, Leustek et al. 2000).

Table 2. The efficient yields of alkaloids indigo and indirubin as influenced by interaction of nitrogen and sulfur. Means \pm SDs, $n=3$, different letters indicate significant difference between treatments using the Dunnett test at $P \leq 0.05$. For different treatments, see Fig. 1.

\begin{tabular}{lll}
\hline Treatments & Indigo $\left[\mu \mathrm{g} \cdot \mathrm{g}^{-1}(\mathrm{~d} . \mathrm{m}).\right]$ & Indriubin $\left[\mu \mathrm{g} \cdot \mathrm{g}^{-1}(\mathrm{~d} . \mathrm{m}).\right]$ \\
\hline N1S0 & $3.45 \pm 0.18 \mathrm{~d}$ & $1.18 \pm 0.00 \mathrm{~d}$ \\
N1S1 & $7.38 \pm 0.11 \mathrm{a}$ & $1.97 \pm 0.06 \mathrm{~b}$ \\
N1S2 & $6.83 \pm 0.10 \mathrm{~b}$ & $1.84 \pm 0.02 \mathrm{c}$ \\
N1S3 & $2.23 \pm 0.11 \mathrm{e}$ & $1.15 \pm 0.02 \mathrm{~d}$ \\
N1S4 & $1.20 \pm 0.04 \mathrm{~g}$ & $0.36 \pm 0.03 \mathrm{ij}$ \\
N2S0 & $0.60 \pm 0.09 \mathrm{j}$ & $0.54 \pm 0.01 \mathrm{~h}$ \\
N2S1 & $0.60 \pm 0.04 \mathrm{j}$ & $0.59 \pm 0.00 \mathrm{~g}$ \\
N2S2 & $4.93 \pm 0.19 \mathrm{c}$ & $2.58 \pm 0.06 \mathrm{a}$ \\
N2S3 & $1.47 \pm 0.15 \mathrm{f}$ & $0.60 \pm 0.00 \mathrm{~g}$ \\
N2S4 & $0.61 \pm 0.02 \mathrm{j}$ & $0.55 \pm 0.02 \mathrm{~h}$ \\
N3S0 & $0.91 \pm 0.01 \mathrm{i}$ & $0.85 \pm 0.01 \mathrm{f}$ \\
N3S1 & $1.11 \pm 0.03 \mathrm{gh}$ & $0.94 \pm 0.01 \mathrm{e}$ \\
N3S2 & $1.43 \pm 0.04 \mathrm{f}$ & $0.83 \pm .01 \mathrm{f}$ \\
N3S3 & $1.03 \pm 0.01 \mathrm{hi}$ & $0.39 \pm 0.02 \mathrm{i}$ \\
N3S4 & $0.92 \pm 0.00 \mathrm{i}$ & $0.33 \pm 0.00 \mathrm{j}$ \\
\hline
\end{tabular}

\section{References}

Aharoni, A., Galili, G.: Metabolic engineering of the plant primary-secondary metabolism interface. - Curr. Opin. Biotechnol. 22: 239-244, 2011.

Davidian, J.C., Kopriva, S.: Regulation of sulfate uptake and assimilation-the same or not the same? - Mol. Plant. 3: 314325, 2010.

De Bona, F.D., Fedoseyenko, D., Von Wirén, N, Monteiro, F.A.: Nitrogen utilization by sulfur-deficient barley plants depends on the nitrogen form. - Environ. exp. Bot. 74: 237-244, 2011.

Fernández, E., Galván, A., Quesada, A.: Nitrogen assimilation and its regulation. - In: Rochaix, J.D., GoldschmidtClermont, M., Merchant, S. (ed.): The Molecular Biology of Chloroplasts and Mitochondria in Chlamydomonas. Advances in Photosynthesis and Respiration. Vol. 7. Pp. 637659. Springer-Verlag, Dordrecht 1998.

Gerhards, N., Neubauer, L., Tudzynski, P., Li, S.M.:
Tryptophan is a precursor of indigo. Thus, APR may affect the synthesis of indigo. The synthesis pathway of indirubin needs some important precursors including indoxyl, indole, anthranilate, and chorismate (Marcinek et al. 2000). Anthranilate synthesis is closely related with ammonium (Mentzen et al. 2008, Gerhards et al. 2014, Xu et al. 2014) and GS is an N metabolism enzyme which also participates in the metabolism of ammonium (Miflin 1974, Fernández et al. 1998, Rosales et al. 2011). Thus, it may explain the relationship of indirubin yield with expression of the GS gene. The expression of the $N R$ gene increased with increasing $\mathrm{N}$ concentration, whereas expressions of $G S, G O G A T$, and $A P R$ mostly decreased. Principle component analysis results indicate that N2S2 was the optimal nutrition of I. indigotica. Manipulating the ratio of $\mathrm{N}$ and $\mathrm{S}$ might be an effective way to achieve higher yields of indigo and indirubin.

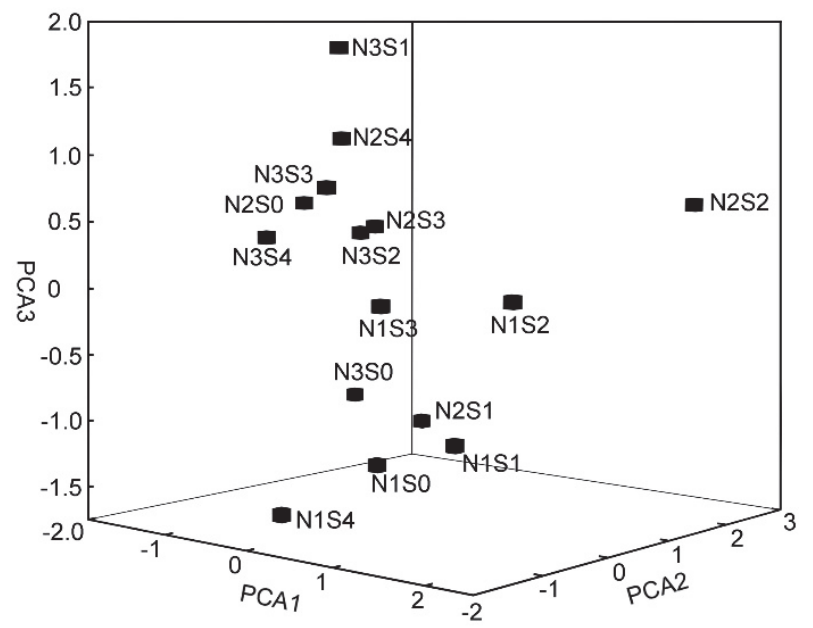

Fig. 4. Principle component analysis of biochemical parameters and gene expressions related to nitrogen and sulfur metabolism under various nitrogen and sulfur concentration in Isatis indigotica. For different treatments, see Fig. 1.

Biosynthetic pathways of ergot alkaloids. - Toxins 6: 32813295, 2014.

Giordano, M., Raven, J.A.: Nitrogen and sulfur assimilation in plants and algae. - Aquat. Bot. 118: 45-61, 2014.

Guan, J.L., Wang, G., Chen, X., Zhang M.R., Miao, Y.J., Tang X.Q.: Effect of low nitrogen nutrition on the growth and active components of Isatis indigotica Fort. seedlings. - Chin. J. Ecol. 37: 2331-2338, 2018.

Herms, D.A., Mattson, W.J.: The dilemma of plants: to grow or defend. - Quarterly Rev. Biol. 67: 282-335, 1992.

Hesse, H., Nikiforova, V., Gakière, B., Hoefgen, R.: Molecular analysis and control of cysteine biosynthesis: integration of nitrogen and sulphur metabolism. - J. exp. Bot. 55: 12831292, 2004.

Hoagland, D. R., Arnon, D. I.: The water-culture method for growing plants without soil. - Calif. Agr. Exp. Sta. Bull. 50: 
$463-485,1950$

Hol, W.H.G., Vrieling, K., Van Veen, J.A.: Nutrients decrease pyrrolizidine alkaloid concentrations in Senecio jacobaea. New Phytol. 158: 175-181, 2003.

Kopriva, S., Calderwood, A., Weckopp, S.C., Koprivova, A.: Plant sulfur and big data. - Plant Sci. 241: 1-10, 2015.

Leustek, T., Martin, M.N., Bick, J.A.: Pathways and regulation of sulfur metabolism revealed through molecular and genetic studies. - Annu. Rev. Plant Biol. 51: 141-165, 2000.

Leustek, T., Saito, K.: Sulfate transport and assimilation in plants. - Plant Physiol. 120: 637-644, 1999.

Livak, K.J., Schmittgen, T.D.: Analysis of relative gene expression data using real-time quantitative PCR and the $2^{-\Delta \Delta C T}$ method. - Methods 25: 402-408, 2001.

Maeda, H., Dudareva, N.: The shikimate pathway and aromatic amino acid biosynthesis in plants. - Annu. Rev. Plant Biol. 63: 73-105, 2012.

Marcinek, H., Weyler, W., Deus-Neumann, B., Zenk, M.H.: Indoxyl - UDPG - glucosyltransferase from Baphicacanthus cusia. - Phytochemistry 53: 201-207, 2000.

Mentzen, W.I., Peng, J.L., Ransom, N., Nikolau, B.J., Wurtele, E.S.: Articulation of three core metabolic processes in Arabidopsis: fatty acid biosynthesis, leucine catabolism and starch metabolism. - BMC Plant Biol. 8: 76, 2008.

Miflin, B.J.: The location of nitrite reductase and other enzymes related to amino acid biosynthesis in the plastids of root and leaves. - Plant Physiol. 54: 550-555, 1974.

Murchie, E.H., Pinto, M., Horton, P.: Agriculture and the new challenges for photosynthesis research. - New Phytol. 181: 532-552, 2009.

Parry, M.A.J., Reynolds, M., Salvucci, M.E., Raines, C., Andralojc, P.J., Zhu, X.G., Price, G.D., Condon, A.G., Furbank, R.T.: Raising yield potential of wheat. II. increasing photosynthetic capacity and efficiency. - J. exp. Bot. 62: 453467, 2011.

Raza, M.A., Feng, L.Y., Manaf, A., Wasayac, A., Ansar, M., Hussain, A., Khalid, M.H.B., Iqbal, N., Xi, Z.J., Chen, Y. K., Chen, J.X., Yang, F., Yang, W.Y. : Sulphur application increases seed yield and oil content in sesame seeds under rainfed condition. - Field Crops Res. 218: 51-58, 2018.

Rentsch, D., Schmidt, S., Tegeder, M.: Transporters for uptake and allocation of organic nitrogen compounds in plants. FEBS Lett. 581: 2281-2289, 2007.

Rosales, E.P., Iannone, M.F., Groppa, M.D., Benavides, M.P.:
Nitric oxide inhibits nitrate reductase activity in wheat leaves. - Plant Physiol. Biochem. 49: 124-130, 2011.

Salvagiotti, F., Castellarin, J.M., Miralles, D.J., Pedrol, H.M.: Sulfur fertilization improves nitrogen use efficiency in wheat by increasing nitrogen uptake. - Field Crops Res. 113: 170177, 2009.

Salvagiotti, F., Miralles, D.J.: Radiation interception, biomass production and grain yield as affected by the interaction of nitrogen and sulfur fertilization in wheat. - Eur. J. Agron. 28: 282-290, 2008.

Scherer, H.W.: Sulphur in crop production. - Eur. J. Agron. 14: 81-111, 2001.

Singh, A., Pandey, B., Kumari, S., Agrawal, M.: Nitrogen availability modulates $\mathrm{CO}_{2}$-induced responses of Catharanthus roseus: biomass allocation, carbohydrates and alkaloids profile. - JARMAP 2: 160-167, 2015.

Sorin, E., Etienne, P., Maillard, A., Zamarreño, A.M., GarciaMina, J.M., Arkoun, M., Jamois, F., Cruz, F., Yvin, J.C., Ourry, A.: Effect of sulphur deprivation on osmotic potential components and nitrogen metabolism in oilseed rape leaves: identification of a new early indicator. - J. exp. Bot. 66: 61756189, 2015.

Tsujimoto, Y., Inusah, B., Katsura, K., Fuseini, A., Dogbe, W., Zakaria, A.I., Fujihara, Y., Oda, M., Sakagami, J.I.: The effect of sulfur fertilization on rice yields and nitrogen use efficiency in a floodplain ecosystem of northern Ghana. Field Crops Res. 211: 155-164, 2017.

Wink, M.: Evolution of secondary metabolites from an ecological and molecular phylogenetic perspective. - Phytochemistry 64: 3-19, 2003.

Xiao, Y.H., Zhao, X.L., Wang, K.C., Shi, X.M., Tang, X.Q.: Effect of different nitrogen forms and concentrations on biomass and alkaloids of Isatidis Folium. - Chin. J. Chin. Master Med. 38: 2755-2760, 2013.

$\mathrm{Xu}$, W., Gavia, D.J., Tang, Y.: Biosynthesis of fungal indole alkaloids. - Nat. Prod. Rep. 31: 1474-1487, 2014.

Zhao, J., Zhu, W.H., Hu, Q., Wang, W.K.: Regulation of indole alkaloids synthesis and related enzymes during callus initiation and culture of Madagascar periwinkle leaves (Catharanthus roseus). - Chin. tradit. herbal Drugs 7: 533$537,1999$.

Zhou, W., Zhang, X.Y.: Research progress of Chinese herbal medicine Radix isatidis (banlangen). - Amer. J. Chinese Med. 41: 743-764, 2013. 